\title{
Supporting grandparent/grandchild contact under the Care of Children Act 2004: Assessment and a call for change
}

\author{
Richard Fisher ${ }^{1}$ and Trudy Hutton-Baas ${ }^{2}$
}

${ }^{1}$ Open Polytechnic, New Zealand

${ }^{2}$ Independent Social Worker, New Zealand
AOTEAROA

NEW ZEALAND SOCIAL WORK 29(3), 30-41.

CORRESPONDENCE TO:

Richard Fisher

Rick.Fisher@

openpolytechnic.ac.nz

\begin{abstract}
INTRODUCTION: The Care of Children Act 2004 reformed the law of child guardianship in Aotearoa New Zealand. However, it did not result in any special legal standing for grandparents seeking contact with their grandchildren, so as to ensure their continued presence in a grandchild's life following a relationship breakdown, or where contact is resisted.

METHODS: Non-doctrinal policy law research methods were used to analyse policies that were relied upon during the law's promulgation, impacts of the law since its enactment, and associated issues that have arisen in its application by practitioners. Litigation to date involving grandparental rights of contact was studied, using Westlaw New Zealand, including its family law suite of searchable databases.
\end{abstract}

FINDINGS: The research revealed a number of processes available under the Care of Children Act and associated family law legislation which may be helpful to grandparents who seek contact with grandchildren. However, none of them resolve the central issue of lack of legal standing, which continues to be an important impediment for grandparents who seek assurance of continuing contact with their grandchildren following family breakdown.

CONCLUSIONS: Examples of law changes which have occurred in other jurisdictions, notably Canada, are offered in support of reform of the Care of Children Act, which would bring Aotearoa New Zealand more in line with other, more progressive countries in its treatment of grandparent/grandchild relationships.

KEYWORDS: care of children; grandparent; contact; parenting order

The purpose of the present research is to investigate the options that are available to social work practitioners working with families to support grandparent/grandchild relationships, particularly where family relationships have broken down. It excludes situations where there is a risk of harm to the child, or where there are child protection issues, in order to concentrate on more garden variety family disputes, where contact is resisted by one or more of the child's parents or guardians. As a result of substantial family law reform that has occurred since 2004, there has been a major shift away from the Family Court as an arbiter of such disputes, to self-resolution (Henaghan et al., 2015). As a result, there are now a number of alternatives available to families who wish to resolve disputes about grandparental access, requiring concomitant knowledge of these processes by practitioners. This research critically assesses options that are available under the Care of Children Act 2004 for grandparents who seek contact with their grandchildren, where deficiencies continue to exist, and what might be done to change the situation. 
The present work adopts currently accepted methods for non-doctrinal, policy law research. For clarity, non-doctrinal research is context-directed legal research that considers more than what the law is, by expanding the scope of analysis to include policies that might have been relied upon during the law's promulgation, impacts of the law since its enactment, and any associated issues that have arisen in its application by practitioners (Chynoweth, 2008). While such analyses are generally non-quantitative, they may have a strong empirical basis. The originality of the data that underpin nondoctrinal policy research (including the present study) includes providing new contexts for examining existing law, an objective analysis of the law itself and how it applies to the new context, an analysis of any associated secondary information, and, finally, confirmation of current interpretations of the law, relying upon an appropriate case law citator (Dobinson \& Johns, 2007). The online citator used in this research was Westlaw New Zealand, including its family law suite of searchable databases.

The traditional role of grandparent as "an orientation of pleasure without responsibility" (Dellman-Jenkins, Blankemeyer, \& Olesh, 2002) has altered substantially in Aotearoa New Zealand since enactment of the Care of Children Act. For example, the Families Commission reported in 2009 that there were approximately 700,000 grandparents in New Zealand, of whom $69 \%$ looked after one or more grandchildren on a regular basis, with $56 \%$ seeing one or more grandchildren at least once a week (Families Commission, 2009). More recent census data show that the number of extended families living together in New Zealand has increased by more than $50 \%$ since 2001 . Of these, more than 50,000 families consisted of three or more generations. The census also shows that $18 \%$ of people aged $65+$ years old include, as unpaid activities, looking after children (Statistics New Zealand, 2014).
The total number of grandparents in Aotearoa New Zealand who either have care of, or otherwise regularly see, their grandchildren, is difficult to determine. That is due to a large degree of informal kinship care, particularly among Māori, that may not come to the attention of social agencies which would otherwise record these statistics (Worrall, 2009). Consequently, while grandparental involvement in care continues to increase in Aotearoa New Zealand, the informal nature of its support makes a determination of absolute numbers problematic.

A number of worldwide trends are associated with these increases, including increased life expectancy, decreases in family size, the rise of single-parent families, and increased maternal employment (Duniform, 2013). For example, a childcare survey conducted in 2009 showed that of $44 \%$ of parents in Aotearoa New Zealand who rely on informal early childhood care for their pre-schoolers, more than $31 \%$ of this care was provided by grandparents (Statistics New Zealand, 2010). The value of grandparents extends beyond their immediate practical value to parents. It has been recognised across a wide spectrum of social activities, including help with homework (Biscoglio \& Wanger, 2011), reducing depression and improving selfesteem in grandchildren (Ruiz \& Silverstream, 2007), stepping in when parents engage in substance misuse (Templeton, 2012, and transmitting religious and cultural values (Ofahanguae Vakalahi, Taiapa, \& Ware, 2013).

Recognition of a grandparent's importance is part of the Whānau Ora (healthy families) Māori health delivery framework (Kara et al., 2011), particularly in the context of guidance from kaumātua (elders). Within Māori, high levels of Whānau (extended family) connectedness have been found to mitigate declines in adolescent mauri ora (individual health) over time. While the concept of Whānau does not always require kinship ties, grandparents related by blood play a key role in the transmission of culture and retention of values that promote connectedness (Stuart \& Jose, 2014). 
Grandparents also benefit from the relationship. It provides them with the ability to resolve some of the issues associated with psychosocial crises that occur in mid-life, and the ability to achieve what Meyers and Perrin (1993) define as "ego integrity" and "generativity": confirmation that an older adult's life has not been lived in vain, and a strong desire to foster relationships with grandchildren to do so. In support of this view, a study of Māori men and women $70+$ years in age found that both men and women self-nominated the importance of Whānau and mokopuna (grandchildren) above all other activities in maintaining active, vibrant lives (Wright, Kepa, Keeling, Connolly, \& Dyall, 2012). Relationships with grandchildren also allow Māori grandparents to transmit cultural knowledge (Ofahengaue et al., 2013). Intergenerational learning provides key information and attitudes that can be quite distinct from those of parents. For example, the transmission of language in Chinese immigrant families $(\mathrm{Ng}, \mathrm{He}, \&$ Loong, 2004) and Tokelauan people (Pene, Peita, \& Howden-Chapman, 2009) living in Aotearoa New Zealand may improve if grandparents are involved, in comparison to more superficial communication that may occur between children and their parents. Aroha (unconditional love) needs space in which to flourish. Blocks to access can be detrimental to grandparental mauri ora, and prevent the passing on of key cultural knowledge of benefit to a child's wellbeing and survival (Butts, Thang, \& Yeo, 2012).

Unfortunately, grandparents may find themselves cut off from their grandchildren, most often where there has been a breakdown in the relationship between the grandchild's parents or guardians. There is a growing body of research that deals with parental alienation, where members of newly reconstituted families may attempt to shut out other people (including grandparents) from their children's lives (Giancarlo \& Rottmann, 2015). Although it goes beyond the scope of the present research, it is worth noting that this situation may also apply where children at risk have been in the temporary care of grandparents under the Children, Young Persons and Their Families Act 1989. Grandparents may find themselves cut off by resentful guardians to whom care has been returned.

Unmet, disappointed grandparent expectations can result in distress, pain, and depression (Meyers \& Perrin, 1993). Australian research shows profoundly destructive impacts on grandparent health from either limited or total lack of contact (Sims \& Rofail, 2014). These authors frame their research in terms of identity theory, finding that grandparents who see themselves as unsuccessful in their roles as both parents and grandparents are likely to suffer from depression, anxiety, relational aggression, and anger, including thoughts of self-harm.

\section{Origins of the Care of Children Act 2004}

In summary, there is evidence to demonstrate the benefits of ongoing grandparent/grandchild relationships. However, grandparental value does not necessarily result in grandparental entitlement. Worldwide, the legal recognition of rights to access with grandchildren has been based upon parental obligations, and not upon any legally recognised role for grandparents (Draper, 2013).

The Care of Children Act 2004 replaced the Guardianship Act 1968. Its purpose was to modernise attitudes to children and parenting, by prioritising the welfare and best interests of children, and encouraging parents to make their own arrangements for day-to-day care and contact. The legislation replaced access and custody with broader and more flexible notions of parental guardianship, recognising the rights of new partners to be involved in parenting, and allowing more opportunities for counselling and other types of dispute resolution.

Parenting orders are the primary means by which contact with children is confirmed under the act. Section 48 applies to 
both day-to-day care, and contact (i.e., access). It also specifies the manner of contact that may be allowed, including both face-to-face meetings, and also indirect communication by way of letters, telephone calls, or email.

Unfortunately, the Care of Children Act has perpetuated the uncertainty of grandparental rights by focusing on the duties, powers, rights and responsibilities of parents as guardians to their children (Dyhrberg, 2004). At the time of enactment, the select committee that was in charge of promulgating the bill reported favourably that it would provide wider eligibility for relatives to apply for a parenting order, while at the same time requiring leave of the court to do so. Consequently, while the legislation improved the rights of guardians, including applications as of right for new partners to be made additional guardians, grandparents were not accorded the same legal standing.

The few improvements to grandparents offered by the Care of Children Act 2004 include:

- an acknowledgement in the purpose of the act (section 3) of the role that other family members may have in the care of children;

- $\quad$ principles in section 5 related to a child's welfare and best interests that are to guide decision makers, including continuity of care, preservation of identity and culture, and, perhaps of greatest relevance to grandparents, "that a child's relationship with his or her family group, Whānau, hapū, or iwi should be preserved and strengthened";

- a requirement to take account of the child's expressed views about contact (section 6);

- the right of a grandparent to be considered an "eligible person" when seeking a parenting order under section 47 if their own child has died, or is entitled to have contact, but is making no attempt to do so.
Why did the Care of Children Act 2004 not give grandparents greater legal standing to apply for contact as of right, without requiring leave of the Family Court? One possible answer is that the provisions as enacted were considered sufficient to address these rights. To confirm this one way or the other, the following sources of information were reviewed:

- background Ministry of Justice reports;

- the select committee report that accompanied the bill;

- Hansard Parliamentary speeches about the bill during its 1st, 2nd, and 3rd readings.

The select committee report (New Zealand Parliament, 2004a) indicated that the majority of submissions (150/277) were focused on the diversity of family arrangements in the bill, notably its samesex provisions. Other topics included the bill's provisions concerning biological parentage, and abortion rights. In its only reference to grandparents, the committee report considered that the child's parents and guardians should have primary responsibility for a child's care, development, and upbringing, wherever possible. Consequently, grandparents and other relatives were considered secondary to these responsibilities, becoming an integral part of the context of a child's best interest.

Debate of the Care of Children bill occupied 34 hours of parliamentary time (New Zealand Parliament, 2004b). All of the speeches were reviewed. None of them makes reference to grandparents, other than in the context of general approval of the bill's reference to the importance of a child's wider family relationships.

In contrast, in a critical submission to the bill, Massey University's Centre for Public Policy Evaluation (Birks, 2003) identified earlier Ministry of Justice reports on which the extended family provisions in the bill were based. The submission criticises these as being incomplete, unbalanced, and 
Table 1. Summary of Legal Options available for Grandparental (GP) Contact in New Zealand, where there are no Child Protection or Risk of Harm issues

\begin{tabular}{|c|c|c|c|c|}
\hline Option & Process & Authority & Advantages & Disadvantages \\
\hline $\begin{array}{l}\text { Agreement } \\
\text { for GP } \\
\text { contact }\end{array}$ & $\begin{array}{l}\text { Inclusion of GP } \\
\text { contact as part } \\
\text { of guardians' } \\
\text { separation } \\
\text { agreement }\end{array}$ & - none required & $\begin{array}{l}\text { - fast } \\
\text { - interim } \\
\text { - can be incorporated into a } \\
\text { future parenting order }\end{array}$ & $\begin{array}{l}\text { - not enforceable } \\
\text { - requires agreement }\end{array}$ \\
\hline $\begin{array}{l}\text { Consent } \\
\text { order }\end{array}$ & $\begin{array}{l}\text { By agreement, } \\
\text { confirmed by the } \\
\text { court }\end{array}$ & $\begin{array}{l}\text { COCA section } \\
40,41\end{array}$ & $\begin{array}{l}\text { - can be made without } \\
\text { engaging in prior family } \\
\text { dispute resolution } \\
\text { - can specify GP contact } \\
\text { - is enforceable }\end{array}$ & - requires agreement \\
\hline $\begin{array}{l}\text { Parenting } \\
\text { information } \\
\text { programme }\end{array}$ & $\begin{array}{l}\text { Voluntarily, as a } \\
\text { form of self- } \\
\text { resolution, or at } \\
\text { the direction of } \\
\text { a Family Court } \\
\text { judge prior to } \\
\text { proceedings }\end{array}$ & $\begin{array}{l}\text { COCA section } \\
46 \mathrm{O}, 47 \mathrm{~B}(2)\end{array}$ & $\begin{array}{l}\text { - available primarily to } \\
\text { guardians, but useful in } \\
\text { emphasising a child's } \\
\text { perspective and family } \\
\text { importance } \\
\text { - Parenting Through } \\
\text { Separation (a self-resolution } \\
\text { category of PIP) allows GP } \\
\text { participation } \\
\text { - certificate of completion is } \\
\text { a prerequisite prior to a GP } \\
\text { seeking leave to apply for a } \\
\text { parenting order }\end{array}$ & $\begin{array}{l}\text { - participation is voluntary } \\
\text { - does not in itself ensure GF } \\
\text { contact }\end{array}$ \\
\hline $\begin{array}{l}\text { Family } \\
\text { dispute } \\
\text { resolution }\end{array}$ & $\begin{array}{l}\text { By application of } \\
\text { a party prior to } \\
\text { any proceedings, } \\
\text { or at the direction } \\
\text { of a Family Court } \\
\text { judge at any time } \\
\text { thereafter }\end{array}$ & $\begin{array}{l}\text { FDRA section } \\
12 ; \text { COCA } \\
\text { sections } 46 \mathrm{E} \text {, } \\
46 \mathrm{~F}\end{array}$ & $\begin{array}{l}\text { - allows for mediation } \\
\text { of disputes by court- } \\
\text { recognised providers } \\
\text { - is available prior to and after } \\
\text { proceedings commence }\end{array}$ & $\begin{array}{l}\text { - may require Family } \\
\text { Court judge approval } \\
\text { to participate and/or } \\
\text { completion of a parenting } \\
\text { information programme } \\
\text { - cannot be attempted more } \\
\text { than once per year }\end{array}$ \\
\hline Counselling & $\begin{array}{l}\text { At the direction } \\
\text { of a Family Court } \\
\text { judge prior to } \\
\text { proceedings }\end{array}$ & $\begin{array}{l}\text { COCA section } \\
46 \mathrm{G}\end{array}$ & $\begin{array}{l}\text { - free } \\
\text { - confidential } \\
\text { - purpose is to encourage } \\
\text { compliance with any future } \\
\text { court directions/outcomes }\end{array}$ & $\begin{array}{l}\text { - requires prior application } \\
\text { for a parenting order } \\
\text { - requires Family Court Judge } \\
\text { approval to participate } \\
\text { - limited number of sessions } \\
\text { - participation is voluntary }\end{array}$ \\
\hline $\begin{array}{l}\text { Settlement } \\
\text { conference }\end{array}$ & $\begin{array}{l}\text { Convened by the } \\
\text { court }\end{array}$ & $\begin{array}{l}\text { COCA section } \\
46 \mathrm{Q}\end{array}$ & $\begin{array}{l}\text { - available up to the point } \\
\text { of a hearing; may result in } \\
\text { avoidance of a hearing } \\
\text { - flexible outcomes which may } \\
\text { settle all or some of the } \\
\text { outstanding issues and } \\
\text { result in a court order }\end{array}$ & $\begin{array}{l}\text { - likely to require lawyer } \\
\text { involvement } \\
\text { - requires Family Court judge } \\
\text { approval } \\
\text { - only one conference can be } \\
\text { convened }\end{array}$ \\
\hline $\begin{array}{l}\text { Parenting } \\
\text { order (for } \\
\text { contact) }\end{array}$ & $\begin{array}{l}\text { As ordered by } \\
\text { a Family Court } \\
\text { judge, whether } \\
\text { by consent or } \\
\text { litigated }\end{array}$ & $\begin{array}{l}\text { COCA sections } \\
47,48,73\end{array}$ & $\begin{array}{l}\text { - provides certainty of GP } \\
\text { contact } \\
\text { - specifies the type and } \\
\text { quantity of contact } \\
\text { - is enforceable }\end{array}$ & $\begin{array}{l}\text { - almost certain to require } \\
\text { lawyer involvement } \\
\text { - requires leave of the court } \\
\text { to apply unless GP is an } \\
\text { "eligible person" } \\
\text { - requires prior participation } \\
\text { in family dispute resolution }\end{array}$ \\
\hline \multicolumn{5}{|c|}{$\begin{array}{l}\text { Note: Authorising legislation includes the Care of Children Act } 2004 \text { (COCA, including Care of Children } \\
\text { (Parenting Information Programme) Regulations 2014), and the Family Dispute Resolution Act } 2013 \text { (FDRA). }\end{array}$} \\
\hline
\end{tabular}


involving little effective public information or consultation. One of these background reports (Ministry of Justice, 2001) reveals a possible explanation for the lack of special consideration for grandparents during the development of replacement legislation for the Guardianship Act 1968. It states that a number of submitters supported the ability of grandparents to apply for access as of right. However, these supporting submissions appear to have been offset by other submissions that argued that, if the law were to be expanded to consider wider family and Whānau, it should also confirm that parents have greater status than wider family members, so as to avoid bickering among a range of related kin. Thus, it can be argued that the bill's final reference to a situation where "a child's relationship with his or her family group, Whānau, hapū, or iwi should be preserved and strengthened" effectively side-lined a special status for grandparents by virtue of their inclusion as part of a wider family group or Whānau, including siblings, aunties, uncles, and other extended family, where leave of the court should be required for all.

\section{Grandparental contact under the Care of Children Act 2004}

The preferred course of action for grandparents who seek contact with grandchildren under the Care of Children Act 2004 will depend on whether contact is being resisted by one or both of the child's guardians (in a two-parent situation), and whether there is an existing parenting order in place. Normally, such orders will specify whether grandparents have contact rights (section 47A). If there is a dispute between parents subject to a parenting order, it is possible for the parent willing to support contact to seek a court direction clarifying that right. Where disputes between guardians occur, the court may make any order it likes that it thinks proper (section 46R).

Are there less confrontational options than a court order available to grandparents seeking contact with their grandchildren?
To answer this question, the Care of Children Act 2004 and corollary family law legislation were reviewed in order to derive options of practical value to practitioners when advising clients about less confrontational methods for contact.

Table 1 outlines the legal options under the Care of Children Act that are available to grandparents in Aotearoa New Zealand who seek contact with their grandchildren. The options are ranked, in relation to increasing Family Court involvement. When attempting to exercise a choice, grandparents must bear in mind that recent reforms created by the Family Dispute Resolution Act 2013 are designed to encourage parties to resolve their own disputes wherever possible. A Family Court hearing is considered a non-preferred, last resort.

Further analysis of Table 1 results in the following conclusions:

\section{Available options will depend on the} stage of family breakdown. Most of the options listed in Table 1 are mechanisms to assist parties in resolving disputes, hopefully leading to consent to commit to an agreement that can eventually be made an order of the Family Court, without the necessity of a hearing. The easiest of these is specification of grandparental contact in separation agreements made by guardians the time of breakup, or soon thereafter. As noted, these are not legally enforceable in and of themselves, but are very useful when drafting future consent orders, or during subsequent judicial conferences.

Options are interconnected, and some might be bypassed. For example, the mediation processes available under family dispute resolution normally require that parties in dispute first complete a "Parenting Through Separation" course. However, there may be exemptions from completing either a parenting course or family dispute mediation or both, depending upon the circumstances of the case. Obstacles to 
completion may include a party's refusal or inability to attend, inability to participate effectively (e.g., language barriers), or where providers recommend that the option is not suitable. In some cases, parties may be referred to counselling prior to completion of mediation.

The options do not apply if there is a risk of harm to a child, or if contact is being considered under child protection legislation. As noted elsewhere, the present research is directed towards family situations where there is no risk of harm from a grandparent seeking contact with a grandchild. If risk of harm can be demonstrated, both the Care of Children Act and the Children, Young Persons and their Families Act 1989 contain provisions for dealing with the risk. An example under the former legislation could include a parenting order for supervised grandparental contact (section 59).

"Leave of the court" is not explained. An application by a grandparent for a parenting order requires an initial determination about whether they have the legal standing to apply for one. The act specifies who may apply. Those with specified legal standing to apply as of right include parents, guardians, and spouses of parents. However, section 47 of the Care of Children Act also allows applications to be made by "any other person who is a member of the child's family, Whānau, or other culturally recognized family group, and who is granted leave to apply by the court."

Leave of the court is not required for grandparents only where the parent has died, been refused contact, or has a legal entitlement to contact but has made no attempt to exercise it. Grandparents may be surprised to find that, in these circumstances, particularly where their own child has been denied contact, or shows no interest in seeing his/her children, that their legal standing is elevated to one of an "eligible person," where leave of the court to seek a parenting order for contact is not required.
This appears to be a major inconsistency in the legislation.

Otherwise, "leave of the court" is required as a first step when seeking a parenting order. What does leave of the court mean? In practical terms, it means that applicants must complete the eligibility (leave to apply) portion of an application for a parenting order (Ministry of Justice, 2017). The form confirms that the applicant is asking the court to let them apply, on the sole basis that it is in the welfare and best interests of the child(ren). The form includes a space where applicants are to state their role and/or why the court should let them apply, as well as an affidavit (a sworn statement of facts).

The test to be applied when considering an application for leave to apply for a parenting order for contact with a grandchild was considered in Barker v. Cargill (2007). In it, Justice Andrews confirmed that the test includes the following criteria:

"a) the application is not frivolous, vexatious, or vindictive, and

b) the applicant is shown to have an appropriate and sustainable interest in promoting the welfare and best interests of the child, then

c) it is sufficient if the applicant can show there is an arguable case."

The issue in Barker v. Cargill was whether "an appropriate and sustainable interest" by a grandparent in a child was enough to justify an application for contact made against a parent. While the High Court agreed that no higher threshold should apply, the fact that the matter went to litigation points out the potential for a chilling effect on other prospective applicants for leave.

The Westlaw New Zealand legal database was used to search for subsequent cases that have cited Barker v. Cargill. A number were found, allowing for the following broad conclusions about current court interpretations of applications for grandparental leave when seeking a parenting order for contact: 
- evidence that a child's parents have refused to participate in counselling, mediation, or other voluntary processes may add weight to a grandparent's application (S-An v. NLN, 2012); Ibbott v. Westcott, 2016);

- any application which can be shown to be in any way contrary to the best interests of the child is likely to be denied leave (FJFB v. TW, 2015);

- although a successful application still requires that the merits of the case are explored in a subsequent hearing, the Family Court may be inclined to give a strong signal of future success or failure during the leave hearing. Examples include a granting of leave accompanied by an order for parties to come to some type of contact arrangement before further proceedings (S v. S, 2006), or an accompanying order for counsel-led mediation (S-Anv. NLN, 2012).

In summary, while the Care of Children Act could be argued as being an improvement upon the Guardianship Act for grandparents who seek contact with their grandchildren, the reality is that litigation about leave applications continues to be an ongoing problem. Resistance tends to follow typical themes, including arguments that the applicant is not really seeking contact, but rather is attempting to control the parent (e.g., Ibbot v. Westcott, 2016), or a floodgates argument, whereby granting leave will lead to a flood of similar applications by other grandparents, leading to a child's interests being subsumed by wider family dynamics ( $S$ v. S, 2006). These wider family dynamics are also used in arguments that grandparents should be treated the same as any other family member listed in the legislation (Eberg v. Bohn-Eberg, 2014) in an attempt to dilute the importance of a grandparent/grandchild relationship. While the Family Court is practised in seeing through hidden agendas, there is little doubt that the requirement to seek leave, and proof of ongoing litigation in this area, continues to produce uncertainty.

\section{Working with grandparents towards a child's "welfare and best interests"}

The need to consider grandparental contact in the different contexts of a child, guardian, and grandparent, indicates the importance of social worker assessment skills. Social workers may be required to report on an application for a parenting order (section 132). They have statutory authority under the Care of Children Act to do so, as they do under the Children, Young Persons and Their Families Act (Henaghan et al., 2015). They may also be required to liaise with other professionals preparing cultural, medical, psychiatric or psychological reports.

Whether grandparents are seeking success in contact via the counselling, parenting, mediation, or litigation provisions of the Care of Children Act, they must be made aware of three key factors that will govern contact under the legislation:

(a) the welfare and best interests of the child are the first and paramount consideration in any decision about grandparental contact;

(b) the purpose and guiding principles in the legislation that may seem to favour contact with grandparents, however laudable, are subservient to a child's welfare and best interests;

(c) in making decisions, any views the child expresses must be taken into account.

In summary, contact is only appropriate if it is in the welfare and best interests of a child. This means that contact is a right of the child, not of a grandparent. Henaghan et al. (2015) suggest contact might be a right of an adult but, if so, it is still subservient to a child's best interest, so the result is effectively the same. For this reason, none of the joy, happiness, and other values that grandchildren provide to grandparents are likely to have merit, if contact is sought solely for these reasons. They have importance only insofar as they support the paramountcy of a child's welfare and best 
interests. As a result, the challenge faced by families is to combine the guiding principles that may apply to a particular family situation (e.g., the principle related to a child's identity) with a child's best interests, so as to show, for example, that preserving and strengthening this child's cultural identity in these circumstances, with this grandparent, will best be served, and will best serve the child's welfare and interests, if there is contact between them.

The most relevant approaches for social workers are likely to be strengths-based (see, e.g., Munford \& Sanders, 2005). They offer value in several contexts, including:

- an emphasis on family competencies, rather than deficits;

- a focus on those aspects of relationships that allow a family to grow;

- finding strengths that families can bring to the table to help the relationship.

Practice models also need to be mindful of the paramountcy of a child's welfare and best interests. For this reason, they are likely to be child-focused and familycentred. Miller (2012) has developed a best interests' case practice model for Australian social workers that illustrates key skills. It recognises approaches that are culturally competent, developmentally informed, gender aware, strengths based, and outcomes focused. Miller's model also draws on ecological theories of human development (e.g., Bronfenbrenner, 1975), which recognises the value of positive change through outside, environmental interventions, while emphasising the central position of a child in relationship with his or her family and community.

\section{Conclusions}

While family law reform that has occurred in Aotearoa New Zealand since the early 2000s suggests that there are now a variety of mechanisms in place to encourage the preservation of grandparent/grandchild relationships, the reality is that New Zealand still requires that grandparents have leave of the court before seeking a parenting order for contact with grandchildren, apart from the limited circumstances permitted by the Care of Children Act. In the period 2006-2007, about $15 \%$ of all applications to the Family Court in New Zealand for parenting orders were made by grandparents (Carson, 2010). Their current success rate is unknown. However, the figures support the view that an increasing number of grandparents would benefit from clarification of their legal standing prior to making an application.

There are a number of reasons for a lack of incentive to change the law. A major obstacle is the inability of grandparents to rely on infringement of their rights under the New Zealand Bill of Rights Act 1990. In contrast to Aotearoa New Zealand, the majority of provinces in Canada have enacted legislation that has elevated the legal status of grandparents (Adcox, 2016). Changes have come as a result of concern that grandparents could raise a legal challenge under the Canadian Charter of Rights and Freedoms to legislation that does not grant such rights (Department of Justice, 2002). The framework for Aotearoa New Zealand's bill of rights legislation is based in part on Canada's Charter (Joseph, 2001). However, the Aotearoa New Zealand legislation cannot be used to "strike down" legislation that is inconsistent with its provisions. That is because Aotearoa New Zealand backed away from this possibility when enacting the NZBRA. No law in New Zealand is invalid merely by reason of being inconsistent with the NZBRA (see section 4). This contrasts with Canada's situation, where the courts do not hesitate to invalidate laws that are inconsistent with the Charter, requiring either a change to the legislation, or by striking it. As a result, while there might be a variety of objections a grandparent might raise under the NZBRA to their lack of standing in New Zealand legislation (e.g., freedom from discrimination), there is no scope for a meaningful result by challenging the law on this basis. 
Legal challenges that rely on the Treaty of Waitangi would also be unlikely to succeed. The Treaty of Waitangi is an agreement between Māori and the Crown that sets out the rights and responsibilities of each, and of all New Zealanders. Articles 1 and 3 of the Treaty provide Māori with the rights of equal citizenship, while Article 2 guarantees rangatiratanga (the right to self-determination), affirming the rights of Māori to live as Māori, and to develop their taonga (culturally prized objects and resources). While a case might be made that visitation with grandchildren is an absolute right afforded by Article 2, a review of case law by Henaghan et al. (2015) shows that New Zealand courts consider that the Treaty is a partnership between the Crown and Māori, and does not directly impact on the rights of citizens in family law disputes. This situation could well be seen as the imposition of western ideologies upon the potential value of living ancestors for Māori.

A final reason for lack of change may be that grey power movements in other countries are better organised, with louder voices. For example, recent changes to Ontario's childcare laws were driven in large part by provincial advocacy groups claiming to represent more than 75,000 grandparents estranged from their grandchildren, who have been pushing for improvements to the law for more than a decade (Ricciuto, 2016). Countries which continue to resist a change to legal standing, including the United Kingdom and Australia, are nonetheless willing to acknowledge that grandparents seeking contact should not necessarily be placed in the same legal position as other extended family members (Draper, 2013). The challenge in these countries, as in Aotearoa New Zealand, is ensuring that any statutory change that acknowledges a special relationship with grandparents is not made merely by virtue of a person bearing the title of grandparent. However, the same argument could be applied to the new partners of Aotearoa New Zealand parents, who do not require leave of the court when seeking to be appointed as an additional guardian of a child under the Care of Children Act, notwithstanding a casual relationship with that child that may have lasted no more than a year. Further, the law does not require drug checks or other vetting of a new guardian's bona fides, so long as they have not attracted the attention of police (Henaghan et al., 2015).

An example taken from Canadian provincial family law (Nova Scotia Legislature, 2015) shows how straightforward it would be to reform New Zealand law, through a simple change to section 47 of the Care of Children Act ("who may apply for a parenting order") to include (a) a parent or grandparent of the child. If this is considered a bridge too far, Nova Scotia legislation offers another exemplar, whereby a new section 47A could be inserted, to specify that "An 'eligible person' applying for a parenting order specifying contact includes a grandparent." This would allow grandparents legal standing to make an application to seek any of the variety of contacts specified in section 48 , including visitation, or indirect contact by letters, telephone, or email (including Skypetype technologies). The changes would confirm legal standing only. Each application would need to be judged on its merits. In addition, grandparents would require leave of the court if they wished to apply for a parenting order specifying more substantive, day-to-day care.

In the absence of parliamentary will to change the law, social worker advocates will still need current knowledge about the other options available to grandparents who seek to maintain contact with their grandchildren. As noted in the present research, practitioners will benefit from skills that can be applied to child-centred decision making, while at the same time maintaining the agility to consider wider perspectives when seeking win-win-win solutions for children, guardians, and grandparents. 


\section{References}

Adcox, S. (2016). Grandparents' visitation rights in Canada. Retrieved from http://grandparents.about.com/od/ Grandparents-Rights/tp/Grandparents-Visitation-RightsIn-Canada.htm

Biscoglio, J., \& Langer, N. (2011). Grandparents against homework. Educational Gerontology, 25, 109-119.

Birks, S. (2003). Submission to the Justice and Electoral Committee on the Care of Children bill. Retrieved from http://www.massey.ac.nz/ wwcppe/issues/CCBsub.htm

Bronfenbrenner, U. (1975, July). The ecology of human development in retrospect and prospect. Paper presented at the Conference on Ecological Factors in Human Development held by the International Society for the Study of Behavioural Development, Guildford, England.

Butts, D. M., Thang, L. L., \& Yeo, A. H. (2012). Policies and programmes supporting intergenerational relations. Retrieved from http://www.un.org/esa/socdev/family/ docs/BP_INTERGENERATIONALSOLIDARITY.pdf

Carson, T. (2010). The legal rights of grandparents. Retrieved from https://www.grownups.co.nz/finance/ trusts-asset-protection/terry-carson-grandparents-rights/

Chynoweth, P. (2008). Legal research. In A. Knight \& L. Ruddock (Eds.), Advanced research methods in the built environment (pp 28-38). London, UK: John Wiley.

Dellman-Jenkins, M., Blankemeyer, M., \& Olesh, M. (2002). Adults in expanded grandparent roles: Considerations for practice, policy and research. Educational Gerontology, 28, 219-235.

Department of Justice. (2002). Grandparent-grandchild access: A legal analysis. Retrieved from http://www. justice.gc.ca/eng/rp-pr/fl-lf/famil/2003_15/4.html

Dobinson, I., \& Johns, F. (2007). Qualitative legal research. In M. McConville \& W. H. Chui (Eds.), Research methods for law (pp 16-44). Edinburgh, UK: Edinburgh University Press.

Draper, H. (2013). Grandparents' entitlements and obligations. Bioethics, 27, 303-316.

Duniform, R. (2013). The influence of grandparents on the lives of children and adolescents. Child Development Perspectives, 7, 55-60.

Dyhrberg, M. (2004). Grandparents and grandchildren rights and responsibility: A New Zealand Perspective. Retrieved from http://www.mariedyhrberg.co.nz/showfile. php?downloadid $=422$

Families Commission. (2009). Changing roles of grandparents - A quantitative study. Retrieved from http://www.superu.govt.nz/sites/default/files/Changingroles-of-grandparents.pdf

Giancarlo, C., \& Rottmann, K. (2015). Kids come last: The effect of family law involvement in parental alienation. International Journal of Interdisciplinary Social Sciences, 9, 27-42.

Henaghan, M., Atkin, B., Caldwell, J., Clarkson, D., Swadling, K., \& Ballantyne, R. (2015). Family law in New Zealand (17 $7^{\text {th }}$ ed.). Wellington, NZ: LexisNexis.

Joseph, J. A. (2001). Constitutional and administrative law in New Zealand. Wellington, NZ: Brookers.

Kara, E., Gibbons, V., Kidd, J., Blundell, R., Turner, K., \& Johnstone, W. (2011). Developing a kaupapa Māori framework for Whānau Ora. Retrieved from https://www. researchgate.net/publication/234139430_Developing_a_ Kaupapa_Maori_Framework_for_Whanau_Ora

Meyers, J. E., \& Perrin, N. (1993). Grandparents affected by parental divorce: A population at risk? Journal of Counselling and Development, 72, 62-66.

Miller, J. (2012). Best interests case practice model. Retrieved from http://www.dhs.vic.gov.au/_data/assets/ pdf_file/0008/589643/cyf_best_interests_case_practice_ model_summary_guide_09_12.pdf

Ministry of Justice. (2001). Summary analysis of submissions in response to the discussion paper Responsibilities for Children: Especially When Parents Part. Retrieved from https://www.msd.govt.nz/documents/about-msdand-our-work/publications-resources/archive/2001summaryofguardianship.pdf

Ministry of Justice. (2017). Care of Children Act 2004: Approved application pack. Retrieved from https://www. justice.govt.nz/family/care-of-children/when-you-dontagree/disagreements/apply-parenting-order/

Munford, R., \& Sanders, J. (2005). Working with families: Strengths-based approaches. In Nash, M., Munford, R., \& O'Donoghue, K. (Eds.), Social work theories in action (pp. 158-173). London, UK: Jessica Kingsley.

New Zealand Parliament. (2004a). Care of Children Bill: As reported from the Justice and Electoral Committee. Retrieved from https://www.parliament.nz/resource/enNZ/47DBSCH_SCR2788_1/57d7cf72946b9a1b9e7468a 511 ec0f336fc27820

New Zealand Parliament. (2004b). Care of Children Bill: Hansard reading reports. Retrieved from https://www. parliament.nz/en/pb/bills-and-laws/bills-proposed-laws/ document/00DBHOH_BILL5507_1/tab/hansard

Ng, S. H., He, A., \& Loong, C. (2004). Tri-generational family conversations: Communication accommodations and brokering. British Journal of Social Psychology, 43, 449-464.

Nova Scotia Legislature. (2015). Maintenance and Custody Act. Retrieved from http://nslegislature.ca/legc/statutes/ maintenance\%20and\%20custody.pdf

Ofahengaue Vakalahi, H., Taiapa, J., \& Ware, F. (2013). Taonga: Grandchildren the treasures of grandparents. Journal of Cultural Diversity, 20, 114-119.

Pene, G., Peita, M., \& Howden-Chapman, P. (2009). Living the Tokelauan way in New Zealand. Social Policy Journal of New Zealand, 35, 79-92.

Ricciuto, T. (2016, December 17). New rights for grandparents. Niagara Falls Review.

Ruiz, S. A., \& Silverstein, M. (2007). Relationships with grandparents and the emotional wellbeing of late adolescent and young adult grandchildren. Journal of Social Issues, 63, 793-808.

Sims, M., \& Rofail, M. (2014). Grandparents with little or no contact with grandchildren - Impact on grandparents. Journal of Aging Science, 2(1), 1-7.

Statistics New Zealand. (2010). New Zealand childcare survey 2009. Retrieved from http://www.stats.govt.nz/ browse_for_stats/people_and_communities/ Children/ChildcareSurvey_HOTP2009revised/ Commentary.aspx

Statistics New Zealand. (2014). 2013 Census. Retrieved from http://www.stats.govt.nz/Census/2013-census.aspx 
Stuart, J., \& Jose, P. E. (2014). The protective influence of family connectedness, ethnic identity and ethnic engagement for New Zealand Māori adolescents. Developmental Psychology, 50, 1817-1826.

Templeton, L. (2012). Dilemmas facing grandparents with grandchildren affected by parental substance misuse. Drugs Education, Provision and Policy, 19, 11-18.

Worrall, J. (2009). Grandparents and whanau/extended families raising kin children in Aotearoa/New Zealand. Retrieved from http://www.grg.org.nz/What+we+do/ Publications/Research/Research+Report+2009++ A+view+over+time.html

Wright, V. A., Kepa, M., Keeling, S., Connolly, M., \& Dyall, L. (2012). Doing what's important: Valued activities for older New Zealand Māori and non-Māori. Australasian Journal on Ageing, 31, 241-246.

List of cases

Barker v. Cargill (2007). CIV-2006-463-904 (High Ct).

Eberg v. Bohn-Eberg (2014). FAM-2014-004-744 (Fam Ct).

FJFB v. TW (2015). CIV-2015-485-296 (High Ct).

Ibbott v. Westcott (2015). FAM-2015-088-367 (Fam Ct).

$S$ v. $S$ (2006). FAM-2006-063-181 (Fam Ct).

S-An v. NLN (2011). FAM-2011-041-682 (Fam Ct). 